\title{
Cash value added as an indicator of efficiency of issuer's development in crisis economic environment
}

\author{
Roman Zavorotniy \\ Kyiv National Economic University named after Vadym Hetman \\ Ukraine \\ e-mail:roman.zavorotniy@yandex.ua
}

\begin{abstract}
Article is devoted to problems of valuation of development of the Ukrainian issuers by using of a cash value added (CVA), on a base of Boston Consulting Group's approach.

Urgency of problems defines a main goal of the presented research - the analysis of features of CVA formation, an assessment of influence of certain elements on dynamics of this indicator, also the analysis of CVA dynamics as the generalized indicator of the enterprise's economic growth. The author describes structure and dynamics of balance of the Ukrainian oil market; he shows the dependence of a dynamics of earnings before interest (EBI as a large element of CVA) on the oil refineries' commitment. In article it also characterizes effective management of the average cost of the corporate capital according to criterion of economy on financial expenses; the second criterion is maximizing the sum of CVA. The author offers a technique of an application of market rate of WACC in CVA indicator (it allows to estimate efficiency of financial management on the value-based management approach).
\end{abstract}

Keywords: cash value added, weighted average cost of capital, earnings before interest, brutto-investments, oil refinery.

JEL Classification: C10, F43, G32

\section{INTRODUCTION}

Since revolution in the winter of 2013 Ukraine has significantly changed its both economic and civilization orientation. Therefore in the short term the country should solve the problems of integration into more capitalized European investment market. The level of development of the investment market particularly is defined by the standards of corporate governance quality of issuers (in particular, such quality means the timely providing with objective and exhaustive information on development of the issuer to all investors). Unfortunately, the assessment of economic development of the enterprises only through the traditional financial performance (such as ROE, TSR, $\mathrm{P} / \mathrm{E}$ and $\mathrm{P} / \mathrm{S}$ ) is non-efficient in the conditions of the Ukrainian shadow economy and a preponderance of tax optimizing schemes. That's why now the most urgent is the problem of objective assessment of development of the enterprises, which are functioning in the conditions of active transformational shadow economy processes. Also much attention is paid to questions of assess- 
ment of capital management effectiveness through the principles of a value-based management (as a concept of strategic management which is the most focused on investors).

\section{LITERATURE REVIEW}

Some works of F. Weissenrieder (Weissenrieder, 1997), G. Friedl and T. Kettenring (Friedl, Kettenring, 2009), S.Mayers (Brealey, Mayers, 2008), D.Volkov (Volkov, 2005), T.Momot (Momot, 2006), O. Tereschenko (Tereshenko, Babyak, 2013) and other foreign and domestic scientists are devoted to the specified problems. However, this specialists concern the questions of valuation of the business which is functioning in the conditions of a sustainable development of non-shadow economy. Therefore the main purpose of the offered research is the describing the features of valuation of a cash value added (CVA) as the most objective and comprehensive indicator of economic development of the Ukrainian issuers which also excludes an opportunity of a financial information distortion. The additional purpose of an article is the describing of influence of financial management efficiency on CVA dynamics.

\section{Methodology}

In our previous works we were comparing the main versions of gradation of financial indicators of economic growth assessment. Also we were proving opinion on the greatest efficiency of CVA indicator in analysis of any enterprise when the local stock market is insufficiently developed. According to its essence, CVA characterizes a difference between an operational cash flow which is generated by the enterprise in the period, and the current cost of capital expenses in the same period (Pirogov, Kravchuk, 2011, p. 208). The main difference of CVA from other value indicators is that it takes into account the sum of economic depreciation (it considers a possibility of perspective reinvestment of depreciation; profitability of such reinvestment is at the level of the weighted average cost of capital).

Works (Volkov, 2005 ; Weissenrieder, 1997; Zavorotniy, 2014) are devoted to standard problems of CVA calculation. However the presented research explains an assessment of efficiency of financial valuebased management of the enterprise in the conditions of local financial crisis (the activity of such enterprises often is unprofitable, management of financial resources is complicated by reduction of the capital market).

The main data on economic activity of all Ukrainian oil refineries (OR) form an analytical base of offered research. During the analysis of dynamics of CVA it is impossible to ignore dynamics of its main elements. According to the Boston Consulting Group version, the elements of CVA are (Zavorotniy, 2014, p. 87):

$$
\mathrm{CVA}=(\mathrm{EBI}+\mathrm{D})-\mathrm{ED}-\mathrm{BI} * \mathrm{WACC}=\mathrm{CFI}-\mathrm{ED}-\mathrm{BI} * \mathrm{WACC}=\mathrm{CFI}-\frac{\mathrm{E}_{\grave{a}} * \mathrm{WACC}}{(1+\mathrm{WACC})^{\mathrm{n}}-1}-\mathrm{BI}^{*} \mathrm{WACC},
$$

$\mathrm{EBI}$ is an earnings before interest minus depreciation, CFI - net cash-flow before interest, $\mathrm{D}$ - depreciation, ED - economic depreciation, BI - brutto-investments, WACC - weighted average cost of the capital, $\mathrm{n}$ - average period of the exploitation of equipment, Ea is the initial value of depreciable assets.

When we study dynamics of EBI as the weightiest element of CVA, it is necessary to research the current development of a whole oil refinery economic sector. In Figure 1 we have shown a balance of Ukrainian crude oil market since 2007. 


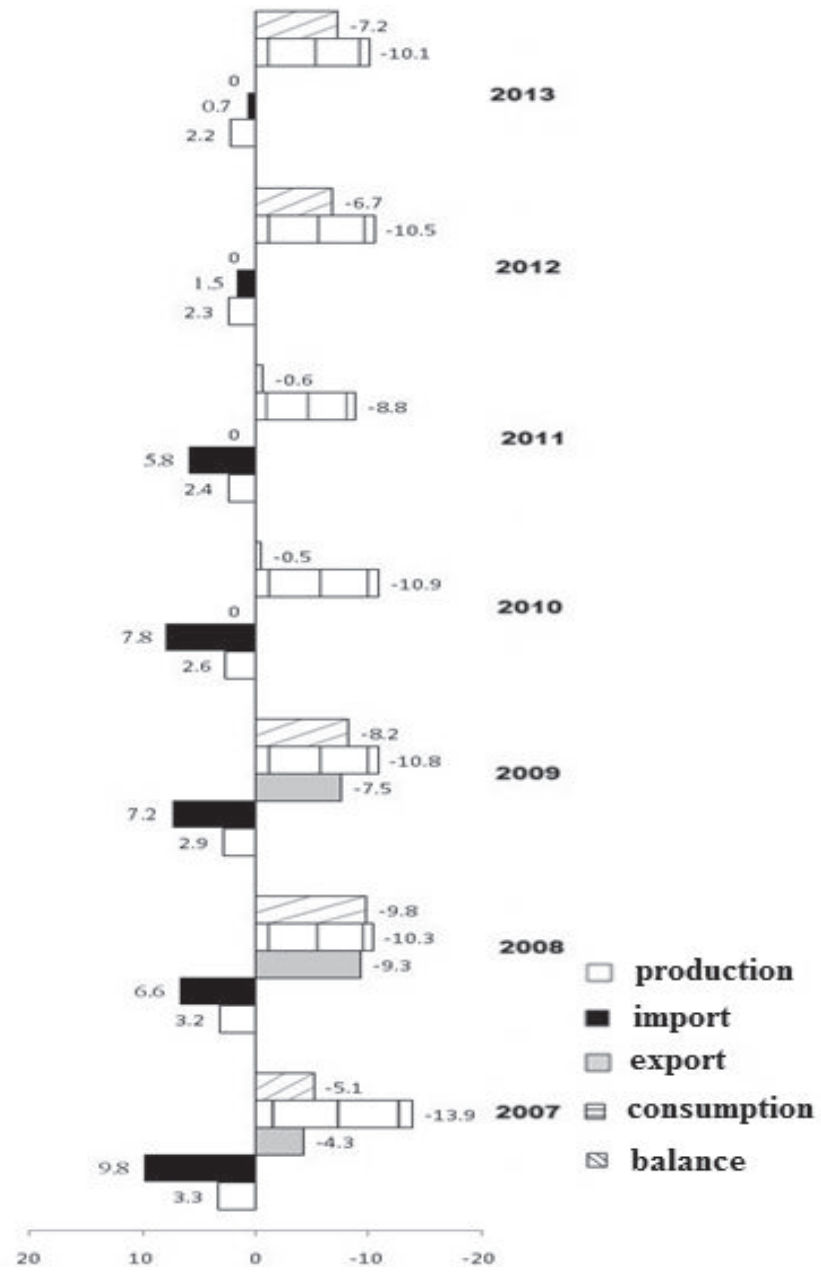

Fig. 1. Balance of the market of oil and crude oil products in Ukraine in 2007-2013, mln. t. Source: made by author by using official statistics and (Sapronov, Kostenko, 2012, p. 63).

Constant negative value of balance (as a combination of supply and demand in the market of oil and crude oil products) shows a preponderance of "grey" trade schemes which concern supply of oil (for example, through the criminal inserts into the oil pipelines). By such "grey" schemes the official statistical consumption volumes are satisfied. As shown in Fig. 1, decrease in balance by $2,1 \mathrm{mln}$. t. (or by $41 \%$ ) during all period was generally causing by gradual reduction in volumes of the imported oil (by $9,1 \mathrm{mln}$. t. or decrease by $93 \%$ ) and reduction of motor oil consumption by $3,8 \mathrm{mln}$. t. (or decrease by $27 \%$ ). Reduction in national economy owing to system crisis in the market, inefficient state program "Ethanol" (Resolution No. 1044, 2000) and state programs for oil import diversification (Resolution No. 1572, 2000), inefficient tax legislation were causing such reduction in oil consumption. It caused permanent stops of oil refineries which officially their CEOs were describing by some modernizations; also it caused an essential reorienta- 
tion of the Ukrainian market to import oil products by Mozyrskiy (Belarus) and by Mazheykyay's (Litva) oil refineries. Dynamics of the Ukrainian oil refineries' production capacity is represented in Table 1.

Table 1

Dynamics of the Ukrainian oil refineries' production capacity in 2004-2013, mln. t.

\begin{tabular}{|l|c|c|c|c|c|c|c|c|c|c|c|}
\hline \multirow{3}{*}{ Oil refineries } & \multicolumn{10}{|c|}{ Years } & \multirow{2}{*}{$\begin{array}{c}\text { Project } \\
\text { capacity }\end{array}$} \\
\cline { 2 - 15 } & 2004 & 2005 & 2006 & 2007 & 2008 & 2009 & 2010 & 2011 & 2012 & 2013 & \\
\hline Lisichanskiy & 6,61 & 6,01 & 4,93 & 5,65 & 4,06 & 4,95 & 4,81 & 4,94 & 0,8 & 0 & 16 \\
\hline Kremenchugskiy & 6,6 & 5,99 & 6,31 & 5,62 & 2,71 & 3,19 & 3,61 & 3,12 & 3,09 & 2,45 & 18,6 \\
\hline Nadvirnyanskiy & 1,77 & 2,06 & 1,32 & 0,86 & 0,32 & 0,15 & 0,19 & 0,14 & 0 & 0 & 2,6 \\
\hline Drobobychskiy & 2,18 & 1,06 & 0,82 & 0,66 & 0,57 & 0,42 & 0,37 & 0,16 & 0 & 0 & 3,2 \\
\hline Khersonskiy & 1,56 & 0,87 & 0 & 0 & 0 & 0 & 0 & 0 & 0 & 0 & 7,1 \\
\hline Odesskiy & 2,45 & 1,39 & 0 & 0 & 2,03 & 2,05 & 1,45 & 0 & 0 & 0,35 & 2,8 \\
\hline
\end{tabular}

Source: made by author by using the companies' official reports

As shown in Table 1, since 2007 the Ukrainian oil refineries' production capacity seldom was exceeding $40 \%$ and has caused steady unprofitability of such business. That's why often the values of the biggest element of CVA - EBI - were negative (see Figure 2).

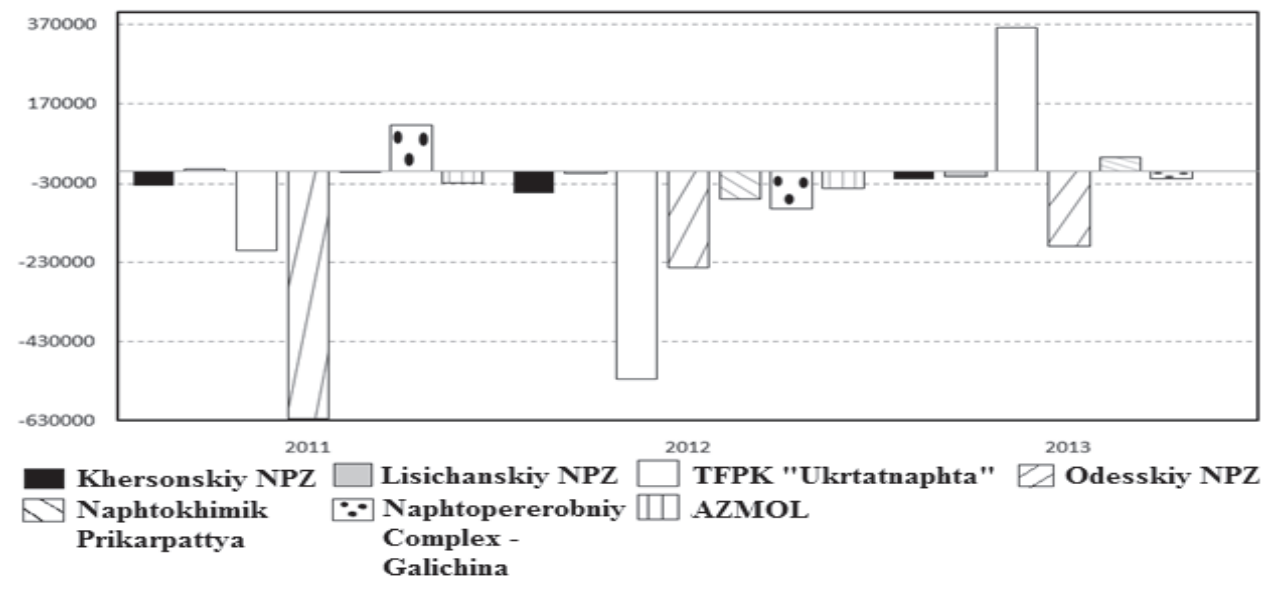

Figure 2. Dynamics of EBI of the Ukrainian oil refineries in 2011-2013, ths. UAH

Source: made by author by using the companies' official reports.

Unprofitability forced oil refineries to start large-scale modernizations. However the analysis have shown that a considerable volumes of non-current assets were not being a main factor of high positive volumes of brutto-investments (see Figure 3), but such role was making by a high specific weight of current assets in a structure of brutto-investments. 


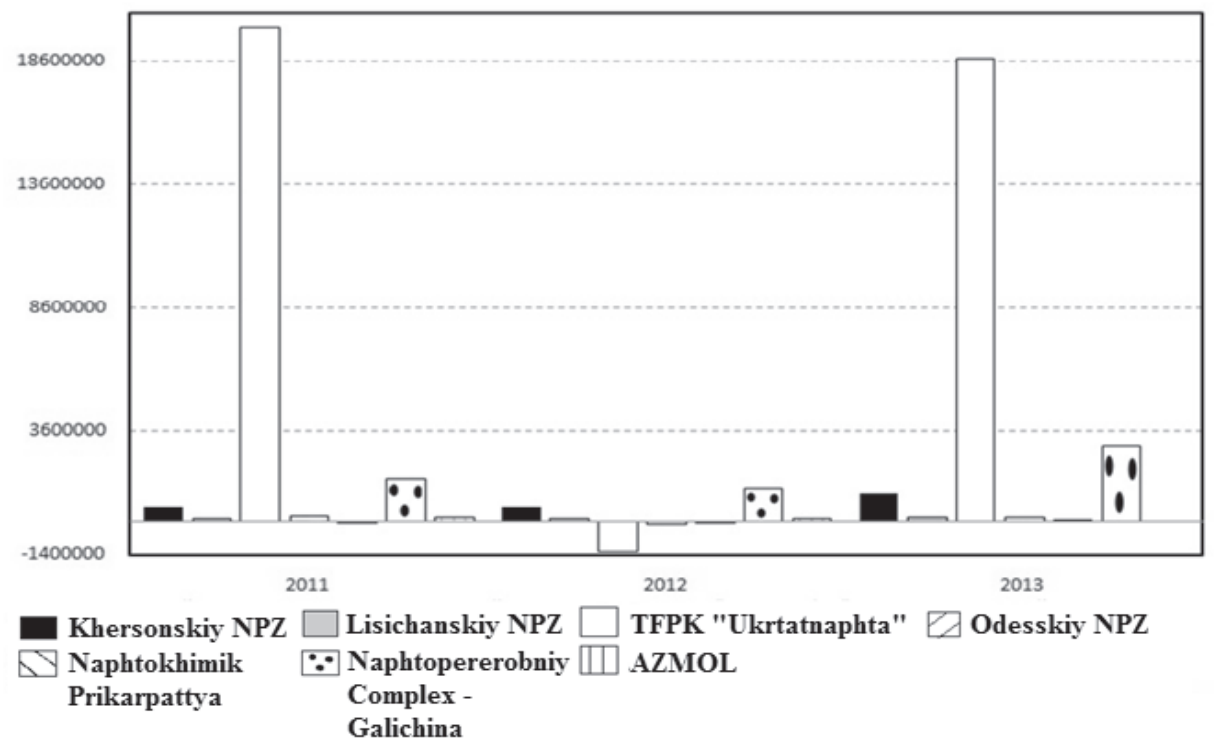

Figure 3. Dynamics of the Ukrainian oil refineries' brutto-investments in 2007-2013, ths. UAH Source: made by author by using the companies' official reports

Often the weighted average cost of the capital (WACC) is used to define a discount rate in the course of the CVA calculation. We think that the efficiency assessment of use of VBM financial instruments, in particular, is made by comparing the following indicators: 1) a volume of CVA according to a book discount rate (the last element is defined through the sum of book expenses to capital lenders and investors; we call it as a book value of WACC), and 2) a volume of CVA for the same period according to market discount rate (the last is defined through the value of financial resources which can be attracted on open financial market; we call it as a market value of WACC).

Models of determination of WACC depend on the purpose of the analysis, features of economic development of the enterprise and analytical base. There can be used: a stakeholder model (Freeman, Moutchnik, 2013), a capital asset pricing model (CAPM) by W. Sharpe (Van Horn, Vakhovich, 2008, p. 664-670), a M. Gordon's model (Brealey, Mayers, 2008, p. 213), a model by J. Lintner (Pirogov, Kravchuk, 2011) and other.

The most of authors defines a weighted average cost of the capital as a profitability rate which investors and creditors wish to get as a gain on using of their money by the enterprise (Blank, 2004, p. 703; Tereshenko, Babyak, 2013, p. 399).

Often experts associate WACC as only one type of value of the corporate capital, but now we want to describe the essence of the book (actual) value of WACC, to show the main goals of its defining and the ways of its using.

As a difference of the market or fair value of WACC (which is wideused in financial analysis), according to our opinion, the book value of WACC is a profitability rate which is implemented into all actual expenses 
which were concerning with use of all corporate financial resources in the current year. In a case when the enterprise has no its preference shares such rate is calculated through a formula (Blank, 2004, p.194-202; Solodov, 2013):

$$
\mathrm{WACC}_{\text {book value }}=\frac{E}{\Sigma C} * \frac{D}{\Sigma E}+\frac{D e b t}{\Sigma C} * \frac{F E}{D e b t_{\text {average }}},
$$

$\mathrm{E}$ is an equity, $\Sigma \mathrm{C}$ is all corporate capital, $\mathrm{D}$ - the sum of dividends and other payments to investors, Debt - the sum of credits and bonds of the enterprise, FE - financial expenses, Debt $t_{\text {average }}$ - average annual sum of the corporate debt.

However, WACC calculation through the other models is aimed only for defining the market or fair rate of a corporate profitability (value of WACC).

In the context of VBM the book value of WACC has to be defined only with a goal of an assessment of financial management efficiency. An assessment can be done according to such criteria:

- the economy on a value of equity or borrowed capital;

- the greater sum of the value which has been generated for a current financial period due to less discount rate (the book profitability which has become less in comparison to an average market rate of a profitability of the similar enterprise in the same period).

To assess the effectiveness of a financial management in the context of VBM, at first, in Table 2 we should compare dynamics of the book and the market values of WACC.

Table 2

The efficiency of oil refineries' financial management in 2011-2013, \%

\begin{tabular}{|c|c|c|c|c|c|c|c|c|}
\hline Year & Performance & $\begin{array}{c}\text { Kher- } \\
\text { sonskiy } \\
\text { NPZ }\end{array}$ & $\begin{array}{l}\text { Lisichan- } \\
\text { skiy NPZ }\end{array}$ & $\begin{array}{c}\text { TFPK «Ukrtat- } \\
\text { naphta" }\end{array}$ & $\begin{array}{l}\text { Odesskiy } \\
\text { NPZ }\end{array}$ & $\begin{array}{l}\text { Naphtokhi- } \\
\text { mik Prikar- } \\
\text { pattya }\end{array}$ & $\begin{array}{c}\text { NPK - } \\
\text { Galichina }\end{array}$ & AZMOL \\
\hline 1 & 2 & 3 & 4 & 5 & 6 & 7 & 8 & 9 \\
\hline \multirow{6}{*}{2011} & Book WACC & 0,63 & 0 & 1,56 & 3,67 & 0 & 0 & 7,33 \\
\hline & Market WACC & 3,68 & 5,4 & 7,32 & 19,5 & 0,32 & 1 & 9 \\
\hline & \multicolumn{8}{|c|}{ Economy on a value: } \\
\hline & - of equity & 6,46 & 6,79 & 8,71 & 6,69 & 6,59 & 6,36 & 6,59 \\
\hline & - of debt & 14,22 & 11,67 & 5,08 & 19,74 & 24,92 & 23,62 & $-7,5$ \\
\hline & - WACC & 3,05 & 5,4 & 5,76 & 15,83 & 0,32 & 1 & 1,67 \\
\hline \multirow{6}{*}{2012} & Book WACC & 0,73 & 0 & 1,02 & 3,49 & 0 & 3,27 & 6,01 \\
\hline & Market WACC & 5,8 & 9,98 & 2,89 & 11,79 & 0,34 & 6,91 & 7,36 \\
\hline & \multicolumn{8}{|c|}{ Economy on a value: } \\
\hline & - of equity & 8,92 & 10,4 & 18,95 & 10,21 & 9,51 & 8,49 & 9,51 \\
\hline & - of debt & 7,49 & 18,19 & 7,61 & 13,13 & 18,19 & 7,19 & $-14,23$ \\
\hline & - WACC & 5,07 & 9,98 & 1,87 & 8,3 & 0,34 & 3,64 & 1,35 \\
\hline \multirow{6}{*}{2013} & Book WACC & 0 & 0 & 0,44 & 1,29 & 0 & 0 & н/д \\
\hline & Market WACC & 1,3 & 2,25 & 2,03 & 21,63 & 0,09 & 5,65 & н/д \\
\hline & \multicolumn{8}{|c|}{ Economy on a value: } \\
\hline & - of equity & 2,5 & 2,54 & 2,74 & 2,53 & 2,52 & 2,49 & н/д \\
\hline & - of debt & 23,89 & 23,89 & 1,25 & 22,39 & 21,39 & 23,89 & $\mathrm{H} /$ д \\
\hline & - WACC & 1,3 & 2,25 & 1,59 & 20,34 & 0,09 & 5,65 & Н/д \\
\hline
\end{tabular}

Source: made by author 
Table 2 shows that the economy on the cost of the capital (WACC) characterizes a difference between the market value of the capital of the enterprises (it is defined through the CAPM) and the book value of their capital (is defined by using the financial reports). We can conclude that the market value of WACC of all enterprises was always exceeding its book value. Such economy was reached through: 1) zero value of equity (because of lack of dividend payments. By their definition, implicit payments for using of corporate equity may not be displayed in financial statements - that's why in the course of calculation we have used a classic methodic (Blank, 2004, p. 195; Solodov, 2013)), \& 2) by low cost of borrowed resources from financial institutions which are a part of common financial and industrial group (as a rule).

Let's define a dynamics of a book CVA according to a specified formula. But, at first, only the regular CVA book values are insufficiently informative and have to be compared to similar CVA values which should be defined by using the market values of WACC of the enterprises. Such analysis allows assessing an efficiency of financial management by criterion of volumes of the CVA generated. To have the correct results we should make the following steps:

- according to Ukrainian accounting standard, the expenses on corporate financial activity belong to an account 140 "Financial Expenses" (such as percentage expenses and commission costs). In another words, to turn the real financial expenses to size of market value of the capital we should multiply the sum of book financial expenses of each enterprise by $\frac{\text { market value of debt }}{\text { book value of debt }}$ ratio. Then may appear some bias caused by the sum of the commission costs (which volume is defined not by a credit rate, but the main sum of a loan);

- volume of income tax (IT) in case of change of a sum of financial expenses (as result of multiplication by ratio of value of a borrowed capital) volumes have to be changed according to a sum:

$$
\mathrm{IT}_{\text {corrected }}=\mathrm{IT}-{ }_{\Delta} \mathrm{FE}_{\text {absolute }} * \mathrm{t} \text {, }
$$

- when ${ }_{\Delta} \mathrm{FE}_{\text {absolute }}$ is an absolute difference between the book financial expenses and the corrected financial expenses (by $\frac{\text { market value of debt }}{\text { book value of debt }}$ ratio), $\mathrm{t}$ - income tax rate;

- it is necessary to correct the earnings before interests and taxation (EBIT) according to a sum of increasing the financial expenses:

$$
\mathrm{EBIT}^{\prime}=\mathrm{EBIT}-{ }_{\Delta} \mathrm{FE} ;
$$

- by using corrected sums of the financial expenses, of EBIT and of income tax we should define the volume of EBI and add it into the CVA formula;

- in the CVA formula it is necessary to replace the book value of WACC with the market value of WACC. Results of the specified list of accounting operations are illustrated in Figure 4.

As shown in Figure 4 almost constantly negative values of CVA are caused by system crisis of the Ukrainian oil market. Besides, the greatest volatility of CVA values is observed at two largest enterprises - OJSC "Odesskiy NPZ” and OJSC "TFPK “Ukrtatnaphta”. As Figure 4, c, shows, the great difference between CVA which were defined by using the book and market values of WACC can be described through the great difference between the values of WACC (according to Table 2, the book value of WACC of OJSC "Odesskiy NPZ" was 5 times lower than its market value in 2011, in 2013 it was 20 times lower because 


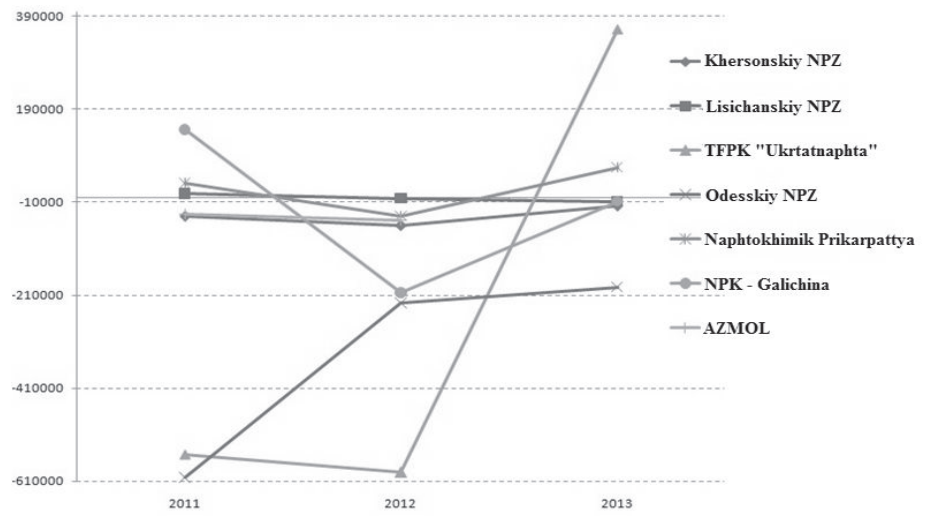

a) dynamics of enterprises' CVA which were defined through the book value of WACC

in 2011-2013, ths. UAH

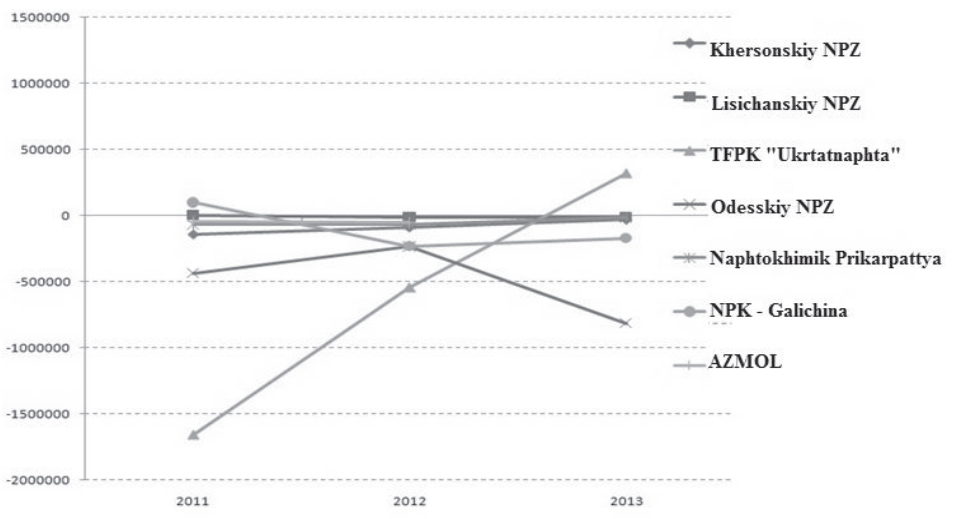

b) dynamics of enterprises' CVA which were defined on a basis of the market value of WACC

in 2011-2013, ths. UAH

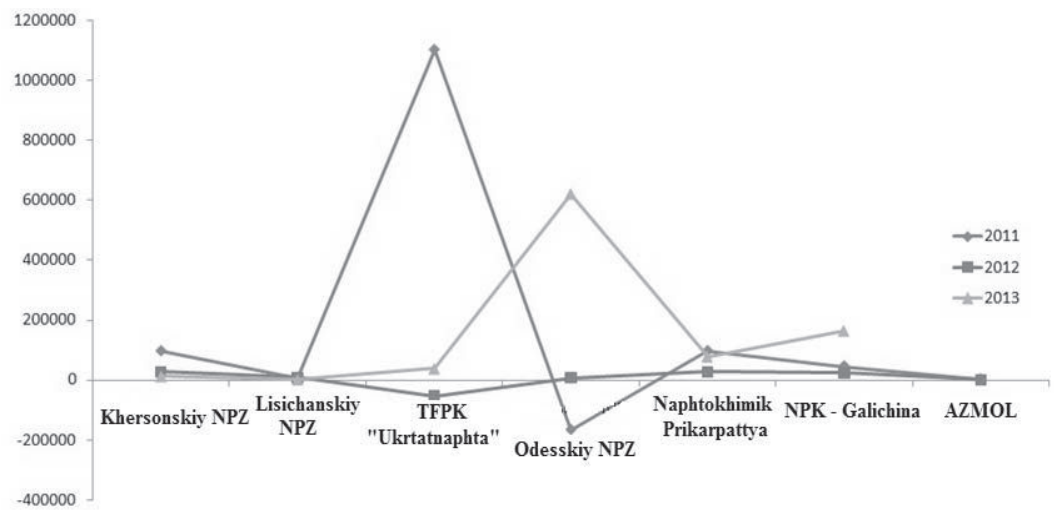

c) dynamics of difference between the enterprises' CVA which were defined through the market value of WACC in 2011-2013, ths. UAH

Figure. 4. Dynamics of Ukrainian enterprises' CVA in 2011-2013, ths. UAH Source: made by author. 
of preferential crediting by "SLB Invest Limited" as a participant of common financial and industrial group "SEPEC").

Because in 2011 OJSC "TFPK "Ukrtatnaphta" was the only one of seven plants which at that time has been recycling oil, at that time it has been having the greatest volumes of current assets and, as result, the greatest volumes of brutto-investments. Therefore the difference between book and market values of WACC has caused the great difference of BI*WACC; the last component has caused the great difference between CVA (on a basis on the book and the market values of WACC) by 1,1 bln. UAH in 2011.

The greatest volumes of the enterprises' financial expenses (despite low book values of WACC) have been a second reason of increasing such CVA of OJSC "Odesskiy NPZ" and OJSC "TFPK "Ukrtatnaphta". If we would correct the book financial expenses according to a $\frac{\text { market value of debt }}{\text { book value of debt }}$ ratio the resulting financial expenses would be increased in several times. We characterize the book financial expenses as abnormally high and as an effective instrument of tax base minimization (because the ratio of market size of such book expenses to all credits is a significantly higher comparing to the value of such borrowed resources according to "Information about the liabilities" of both enterprises). In 2011 the value of borrowed capital of OJSC "TFPK "Ukrtatnaphta" was 19,84\%, at the same time the ratio of the annual financial costs to the total sum of its credits was twice higher $-37,2 \%$. The same ratios relatively to OJSC "Odesskiy NPZ" was $24,92 \%$ and 3,7\% in 2011. That's why the great deviations in EBI were caused by multiplication of the book financial expenses by $\frac{\text { market value of debt }}{\text { book value of debt }}$ ratio. This has become the main factor of the same deviations in CVA which were defined through the book and the market values of WACC.

Volumes of financial expenses of OJSC "Odesskiy NPZ" as its main instrument of tax minimization are the highest (see Table 3) because the financial expenses have been forming over a half of all corporate expenses in 2012-2013.

Table 3

Dynamics of a part of financial costs in all expenses of oil refineries in 2011-2013

\begin{tabular}{|c|c|c|c|c|c|c|c|}
\hline Years & $\begin{array}{c}\text { Khersonskiy } \\
\text { NPZ }\end{array}$ & $\begin{array}{c}\text { Lisichanskiy } \\
\text { NPZ }\end{array}$ & $\begin{array}{c}\text { TFPK «Ukrtat- } \\
\text { naphta" }\end{array}$ & $\begin{array}{c}\text { Odesskiy } \\
\text { NPZ }\end{array}$ & $\begin{array}{c}\text { Naphtokhi-mik } \\
\text { Prikrpattya }\end{array}$ & $\begin{array}{c}\text { NPK - } \\
\text { Galichina }\end{array}$ & AZMOL \\
\hline 1 & 2 & 3 & 4 & 5 & 6 & 7 & 8 \\
\hline 2011 & $15,7 \%$ & $0 \%$ & $0,3 \%$ & $1,7 \%$ & $0 \%$ & $2,9 \%$ & $12,6 \%$ \\
\hline 2012 & $8,9 \%$ & $0 \%$ & $0,3 \%$ & $45,0 \%$ & $0 \%$ & $0,3 \%$ & $14,3 \%$ \\
\hline 2013 & $8,5 \%$ & $8,5 \%$ & $0,4 \%$ & $43,1 \%$ & $5,3 \%$ & $1,4 \%$ & н/д \\
\hline
\end{tabular}

Source: made by author on a basis of the companies' official reports.

Experience of the financial management at the Ukrainian enterprises is shown in Table 2 and in Figure 4, c. Such illustrations describe that in $90 \%$ cases the economy on the book value of WACC (comparing to its market value) has caused a higher CVA size. In the rest of cases (10\%) the abnormally high deviations in CVA were caused by atypical conditions of some enterprises' development (OJSC "Odesskiy NPZ": minimization of a tax base through the increasing of financial expenses, the book value of WACC was 20 times higher than its market value; OJSC "TFPK "Ukrtatnaphta": according to its income statement over 2011 the enterprise has been having the greatest sum of brutto-investments - over $20 \mathrm{bln}$. UAH). 
As the ratios $\frac{\text { market value of the borrowed capital }}{\text { book value of the borrowed capital }}$ and $\frac{\text { market value of WACC }}{\text { book value of WACC }}$ of all enterprises less than 1 we can conclude: in most cases CVA would decrease if we would define the sum of CVA of such enterprises (on a basis of the book value of WACC) through the market value of their WACC:

$$
\mathrm{CVA}_{\text {market value of } \mathrm{WACC}} \downarrow=\mathrm{EBI} \uparrow+\mathrm{D}-\left(\frac{E_{a} * W A C C \uparrow}{(1+W A C C \uparrow)^{n}-1}\right) \downarrow-(\mathrm{BI} * \mathrm{WACC} \uparrow) \uparrow
$$

We shouldn't forget that in 2011-2013 the most part of the Ukrainian oil refineries was not attracting credit resources (see Table 2). Because in most cases the sum of financial expenses of the enterprises equaled to 0 it is not necessary to correct the book financial expenses by $\frac{\text { market value of the borrowed capital }}{\text { book value of the borrowed capital }}$ ratio and to correct the volume of EBI.

Thus, offered research has caused the following conclusions:

Figure 1 shows that the Ukrainian oil refining sector for last 7 years has been coming to decadence. Among all oil refineries there only one is functioning (the OJSC's "TFPK "Ukrtatnaphta" plant is loaded only for 10 percent). The negative balance of the national oil market (see Figure 1) has caused negative annual volumes of an EBI (see Figure 2) which is a main component of corporate CVA.

Need of an assessment of VBM efficiency forced us to develop a technique for CVA correction according to a market value of WACC of the enterprise and related elements of its financial statements. Such technique has allowed us to create a formula of CVA dependence on a difference between the book and the market values of WACC (see an equation 5).

The analysis proved that the Ukrainian oil refineries in most cases were maximizing volumes of CVA (see Figure 4) through the economy on the book value of the capital in comparison with its market value (see equation 5).

\section{REFERENCES}

Blank, I. A. (2004). Finansovaya strategiya predpriyatiya [Financial Strategy Of The Enterprise], Elga, Kyiv, Ukraine, $720 \mathrm{p}$.

Brealey, R. \& Mayers, S. (2008). Printsipy korporativnyh finansov [Principles of Corporate Finance] // Tralsl. from Engl. by N. Baryshnikova, JSC “Olymp-Business”, Moscow, Russian Federation, 1008 p.

Freeman, R., Moutchnik, A. (2013). Stakeholder management and CSR: questions and answers // Umwelt Wirtschaftsforum, Springer Verlag, Vol. 21, Nr. 1, available at: http://link.springer.com/article/10.1007/s00550-013-0266-3 (Accessed 30 November 2013).

Friedl, Gunther, Kettenring, Tim (2009). A Note on the War of Metrics / Gunther Friedl, Tim Kettenring // Control TUM Business School. - 2009, March. - 14 p., available at: http://www.controlling.wi.tum.de/fileadmin/ w00bel/layout/downloads/vorlesungsunterlagen/SS10/VBM/Note_on_War_of_metrics.pdf (Accessed 30 November 2013).

Momot, T. V. (2006). Vartisno-orientovane korporativne upravlinnya: vid teorii do praktichnogo vprovadzhennya: Monographia [Value-Based Corporate Management: From the Theory to Application: Monograph], KNACE, Kharkiv, Ukraine, 380 p.

Pirogov, N. K. \& Kravchuk, D. V. (2011). Model Lintnera: primer razvivayushikhsya rynkov kapitala // Korporativnye finansy [Model by Lintner: Examples Of The Emerging Capital Markets // Corporate Finance], No. 4 (20), 
Moscow, Russian Federation, available at: http://cfjournal.hse.ru/data/2012/02/02/1262786015/CFJ20_5_11_ Pirogov_Kravchuk_.pdf (Accessed 30 November 2013).

Sapronov, Y. A. \& Kostenko, D. M. (2012). Analiz rinku naphty v Ukrainy // Problemy ekonomiky [Analysis Of The Oil Market Of Ukraine // Problems Of Economics], No. 4, RC of the Industrial development problems NASU, Kiyv, Ukraine , pp. 56-67, available at: www.problecon.com/pdf/2012/4_0/56_67.pdf (Accessed 30 November 2013).

Solodov, A. K. (2013). Sfera primeneniya pokazatelya WACC kak instrumenta finansovyh raschyotov // Korporativniy menedzhment [Ways Of WACC Application As An Instrument Of Financial Calculations // Corporate Management], Moscow, Russian Federation, available at: http://www.cfin.ru/management/manufact/scope_wacc.shtml (Accessed 30 November 2013).

Tereshenko, O. O. \& Babyak, N. D. (2013). Finansoviy kontroling: uchebnoe posobie [Financial Controlling: Manual], KNEU, Kyiv, Ukraine, 407 p.

The official site of the Verkhovna Rada of Ukraine (2000). "Pro zatverdzhennya programy "Ethanol" [About The Approval Of The "Ethanol" Program] // Resolution of Cabinet of the Ministers of Ukraine, No. 1044, 04.07.2000. (Accessed 30 November 2013).

The official site of the Verkhovna Rada of Ukraine (2000). "Pro zatverdzhennya Programy diversifikatsii dzherel postachannya naphty v Ukrainu na period do 2015 roku” [About The Approval Of The Program For Diversification Of Oil Supply To Ukraine Until 2015” // Resolution of Cabinet of the Ministers of Ukraine, No. 1572, 08.11.2006, available at: http://zakon4.rada.gov.ua/laws/show/1572-2006- $\bigotimes$ (Accessed 30 November 2013).

Van Horn, J. \& Vakhovich, D. Jr. (2008). Osnovy finansovogo menedzhmenta [Bases Of Financial Management] Vol. 12 // Transl. from English, JSC "Williams", Moscow, Russian Federation, 1232 p.

Volkov, L. (2005). Pokazateli rezultatov deyatelnosti: ispolzovanie v upravlenii stoimostyu kompanii [Economic Results Indicators: Using Of Them In Corporate Value Management], Vol. 3, No. 2, Moscow, Russian Federation: pp. 3-42, available at: http://www.rjm.ru/archive/list/t_3_2_2005_g/novye_issledovaniya/d_1_volkov_pokazateli_rezultatov_deyatelnosti_ispolzovanie_v_upravlenii_stoimostyu_kompanii/ (Accessed 30 November 2013).

Weissenrieder, F. (1997). Value Based Management: Economic Value Added or Cash Value Added? / F. Weissenrieder// Gothenburg Studies in Financial Economics: Study No. 1997:3; Gothenburg University: Gothenburg, available at: http://papers.ssrn.com/sol3/ papers.cfm?abstract_id=156288 (Accessed 30 November 2013).

Zavorotniy, R. I. (2014). Strategicheskoe finansovoe upravlenie stoimostyu predpriyatiya [Strategic Financial ValueBased Management], Lambert Academic Publishing, Saarbrucken, Germany, 236 p. 